CONF-950740--52

WHC-SA-2737-FP

\title{
Stress Evaluation of the Primary Tank of a Double-Shell Underground Storage Tank Facility
}

M. B. Atalay, P.E. ICF Kaiser Engineers Oakland, California

M. D. Stine, P.E. ICF Kaiser Hanford Company

S. K. Farnworth, P.E.

Westinghouse Hanford Company

Date Published

December 1994

To Be Presented at 1995 ASME PVP Conference Honolulu, Hawaii July 23-27, 1995

Prepared for the U.S. Department of Energy Office of Environmental Management
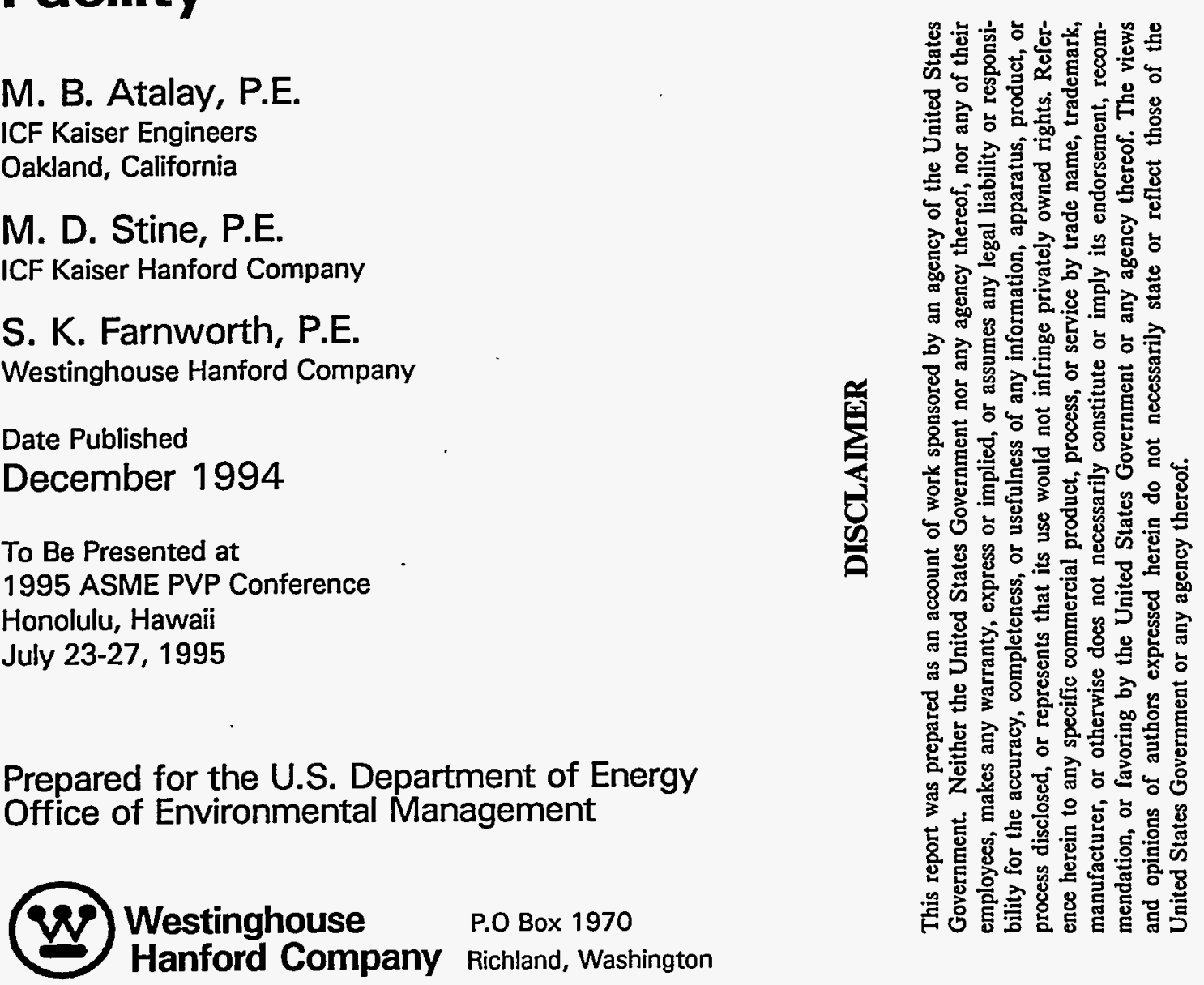

Hanford Operations and Engineering Contractor for the U.S. Department of Energy under Contract DE-AC06-87RL10930

Copyright License By acceptance of this article, the publisher and/or recipient acknowledges the U.S. Government's right to retain a nonexclusive, royalty-free license in and to any copyright covering this paper. 


\section{DISCLAIMER}

Portions of this document may be illegible in electronic image products. Images are produced from the best available original document. 
LEGAL DISCLAIMER

This report was prepared as an account of work sponsored by an agency of the United States Government. Neither the

United States Government nor any agency thereof, nor any of their employees, nor any of their contractors, subcontractors or their employees, makes any warranty, express or implied, or assumes any legal liability or responsibility for the accuracy, completeness, or any third party's use or the results of such use of any information, apparatus, product, or process disclosed, or represents that its use would not infringe privately owned rights. Reference herein to any specific commercial product, process, or service by trade name, trademark, manufacturer, or otherwise, does not necessarily constitute or imply its endorsement, recommendation, or favoring by the United States Government or any agency thereof or its contractors or subcontractors. The views and opinions of authors expressed herein do not necessarily state or reflect those of the United States Government or any agency thereof.

This report has been reproduced from the best available copy.

Printed in the United States of Americe

DISCLM-2.CHP (1-91) 


\section{Stress Evaluation of the Primary Tank of a Double-Shell Underground Storage Tank Facility}

M.B. Atalay, P.E.

ICF Kaiser Engineers Oakland, Ca.

M.D. Stine, P.E.

ICF Kaiser Hanford Company

Richland, Wa.

S.K. Farnworth, P.E.

Westinghouse Hanford Company

Richland, Wa.

Date Published

December 1994

To be presented at 1995 ASME PVP Conference

Honolulu, Hawaii

July 23-27, 1995 


\author{
Stress Evaluation of the Primary Tank \\ of a Double-Shell Underground Storage Tank Facility \\ by \\ M. Bilgin Atalay, P.E. ${ }^{1}$, \\ Marvin D. Stine, P.E. ${ }^{2}$, and \\ Susan K. Farnworth, P.E. ${ }^{3}$
}

\title{
SUMMARY
}

A facility called the Multi-Function Waste Tank Facility (MWTF) is being designed at the Department of Energy's Hanford site. The MWTF is expected to be completed in 1998 and will consist of six underground double-shell waste storage tanks and associated systems. These tanks will provide safe and environmentally acceptable storage capacity to handle waste generated during single-shell and double-shell tank safety mitigation and remediation activities.

This paper summarizes the analysis and qualification of the primary tank structure of the MWTF, as performed by ICF Kaiser Hanford during the latter phase of Title I (Preliminary) design. Both computer finite element analysis (FEA) and hand calculations methods based on the so-called Tank Seismic Experts Panel (TSEP) Guidelines (reference 1) were used to perform the analysis and evaluation.

An axisymmetric FEA model was used to evaluate the tank under the following conditions:

- The normal operating loads of gravity and hydrostatic loading.

- Secondary stresses caused by the thermal expansion of the tank due to the heat transferred by the agitation process and the waste, and the creep and seismic displacements of the primary tank/secondary tank connection point.

- Seismic loads, including the effects of hydrodynamic pressures, tank inertia (negligible compared with the hydrodynamic effects), and sloshing.

Hand calculations based on the closed-form evaluation methodologies presented in the TSEP Guidelines were used to check the following response items:

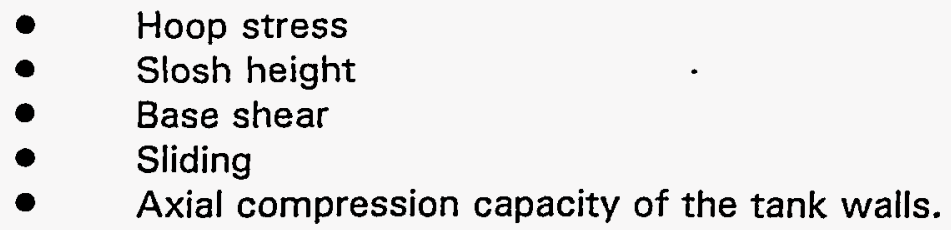

The following additional calculations were also performed:

- parametric calculations for the determination of an optimum bottom knuckle radius,

1 ICF Kaiser Engineers, Oakland, CA

2 ICF Kaiser Hanford, Richland, WA

3 Westinghouse Hanford Company, Richland, WA 
- an evaluation of the bottom plate at locations where it spans unsupported over the cooling channels in the support pad,

- an evaluation of the buckling potential of the bottom plate under the operating vacuum load, and

- calculations to satisfy the thickness requirements of the ASME Code, subarticle NC3900.

Based on the evaluations summarized in this paper, it is concluded that the primary tank structure of the MWTF satisfies the project design requirements specified in the project design criteria and the ASME B\&PV Code. Specifically, the stresses in the tanks induced by the various. service level loads are within the corresponding allowable limits defined in the ASME B\&PV Code, Section III, Division 1, subsection NC, 1992 edition.

In addition, the hand calculations performed using the methodologies provided in the TSEP Guidelines demonstrate that, except for slosh height, the capacities exceed the demand. The design accounts for the adverse effect of the excessive slosh height demand, i.e., inadequate freeboard, by increasing the hydrodynamic wall and roof pressures appropriately, and designing the tank for such increased pressures.

\section{APPROACH AND EVALUATION}

\section{Finite Element Model}

An axisymmetric finite element model of the primary tank steel structure was constructed using the ANSYS computer program (reference 2). The configuration and dimensions used as a basis in constructing the model were taken from the preliminary tank drawing shown in Figure 1. Preliminary evaluations of the compressive stresses at the bottom knuckle indicated that a bottom knuckle thickness of 1 inch was not adequate. Therefore, a thickness of 1-1/8 inch was used as the thickness of the bottom knuckle in the finite element model and in all the subsequent evaluations.

The finite element model utilizes two element types: (i) axisymmetric shell elements with non-axisymmetric loading capabilities representing the primary tank steel, and (ii) twodimensional elements, which may maintain or break physical contact and slide. The latter element type represents the interface between the primary tank steel and the support pad at the bottom of the tank. This element type, i.e., the two dimensional interface element, is active under axisymmetric loading conditions such as thermal expansion, gravity or hydrostatic loading, and is inactive under non-axisymmetric loads, since under such conditions it is meaningless because of computer program limitations. The initial axisymmetric loading is used to determine which of the interface elements break contact at the tank bottom near the bottom knuckle, and that information is used to simulate the boundary conditions during the non-axisymmetric seismic loading. The material properties input are those at the design temperature. A corrosion allowance of $(0.001 \mathrm{inch} / \mathrm{year}) \times$ (50 years design life) has been considered in the shell thicknesses input. An additional erosion allowance of ( 0.003 inch/year) $\times(50$ years design life) has also been considered for the bottom plate, to account for the effects of the mixing pump discharge jet.

The resulting finite element model is shown in Figure 2. 


\section{Normal Operating Loads (Service Level A) Analysis}

The above-described finite element model of the primary tank structure was analyzed under normal operating loads, which consist of:

- the dead load of the tank steel,

- the displacement of the connection point of the primary tank to the concrete structure due to the soil and concrete overburden,

- the hydrostatic pressure for the maximum level of liquid, and

- the design pressure for the vapor space above the maximum liquid level.

The resulting stresses were evaluated against the ASME B\&PV Code, Section III, Division 1 , subsection NC, level A allowables. The service limits shown in the ASME code are as follows:

Subsection NC-3200:

$$
P_{m}+P_{m} \quad \leq \quad 1.0 S_{m}
$$

Subsection NC-3900:

$$
\begin{array}{r}
\sigma_{\mathrm{m}} \leq 1.0 \mathrm{~S} \\
\sigma_{\mathrm{m}}+\sigma_{\mathrm{b}} \leq 1.5 \mathrm{~S}
\end{array}
$$

where $P_{m}$ and $P_{b}$ are the primary membrane and bending stress intensities, $\sigma_{m}$ and $\sigma_{b}$ are the primary membrane and bending stresses, respectively, and $S_{m}$ and $S$ are the allowable design stress intensity and stress values for the material.

Table 1 summarizes the results of this evaluation. Figure 3 shows the displaced shape under the applied normal operating loads. According to the results shown in Table 1, all the evaluated stress components are less than their corresponding allowables, and therefore, the tank design is acceptable under normal operating (service level A) loads.

Table 1 -- ASME Code Stress Evaluations under Normal Operating Loads

\begin{tabular}{||l|c|c||}
\hline & Stress: (ksi) & $\begin{array}{c}\text { Allowable Stress } \\
\text { at Temperature (ksi) }\end{array}$ \\
\hline $\begin{array}{l}\text { Membrane Stress Intensity } \\
\text { per NC-3200 }\end{array}$ & 12.89 & 22.80 \\
\hline $\begin{array}{l}\text { (Membrane + Bending) Stress } \\
\text { Intensity per NC-3200 }\end{array}$ & 23.15 & 34.20 \\
\hline $\begin{array}{l}\text { Membrane Stress } \\
\text { per NC-3900 }\end{array}$ & 12.88 & 17.50 \\
\hline $\begin{array}{l}\text { (Membrane + Bending) Stress } \\
\text { per NC-3900 }\end{array}$ & 23.12 & 26.25 \\
\hline
\end{tabular}




\section{Thermal Loading and Secondary Stress (Service Level B) Analysis}

Service level B mechanical loads are the same as those for the level A category. However, since service level A primary stress intensity limits are lower than the level B limits, no primary stress intensity check is required for the level B limits. Service level B includes steady state loading, transient thermal loading, and the effects of the deformations of the secondary concrete structure.

The MWTF primary tanks will be located underground. They will be supported at the bottom by a reinforced concrete pad and anchored to the concrete at the top at close intervals. This configuration severely limits the vertical thermal expansion of the tank and may produce high thermal stresses. Therefore, it was conservatively determined that an evaluation of thermal stresses is needed, even though such an evaluation is not required by the ASME Code, article NC-3900.

Although heat transfer analyses incorporating numerous steady state and transient thermal load cases has been performed, the design temperature of $250^{\circ} \mathrm{F}$ throughout the tank envelopes the temperature profiles obtained in the heat transfer analyses, and therefore, a uniform temperature distribution of $250^{\circ} \mathrm{F}$ is conservatively used for a single primary tank analysis load case. The displacements at the dome anchor were obtained from a preliminary thermal creep analysis of the secondary concrete structure. Estimates of endof-life displacements were conservatively applied for all thermal cases.

Since the stresses caused by relative seismic displacements are also considered secondary by the ASME Code, the seismic displacements of the connection point of the concrete dome to the primary tank were added to the thermal displacements in a conservative manner and analyzed together. The previously described finite element model was used in the analysis.

The stress acceptance criteria uses the stress limits given in Appendix XIII of Section III of the ASME Code; i.e., primary plus secondary stress intensity $\left(P_{m}+P_{b}+Q\right)$ should be less than $3.0 \mathrm{~S}_{\mathrm{m}}$. The secondary stress analysis calculated the maximum stress intensity to be $42,694 \mathrm{psi}$. Since the calculated stress is less than the allowable limit of $3.0 \mathrm{~S}_{\mathrm{m}}=$ 68,400 psi, the tank design is acceptable under the service level $B$ loads. Figure 4 shows the displaced shape under the applied service level B loads.

\section{Hydrodynamic Pressure Calculations}

The information provided in Chapter 4 of the TSEP Guidelines was used to evaluate the hydrodynamic pressures and forces of liquid motions induced by earthquake ground motion in the liquid storage tanks. The impulsive and convective hydrodynamic pressures $\left(P_{i}\right.$ and $P_{c}$ ) were computed for a horizontal component affected by ground motion. The hydrodynamic wall pressure $\left(P_{v}\right)$ induced by the vertical component of the ground motion was also calculated. A Newmark-Hall type median response spectrum with a ZPA of $0.35 \mathrm{~g}$ was used as the DBE for this analysis. The three hydrodynamic pressures are shown graphically in Figure 5. Table 2 shows the equations and damping values used for computing the hydrodynamic pressures. 
Table 2 -- Hydrodynamic Pressure Calculations Summary

\begin{tabular}{|c|c|c|c|}
\hline Item & Impulsive & Convective & $\begin{array}{c}\text { Vertical Earth- } \\
\text { quake Effect }\end{array}$ \\
\hline Damping value* & $4.0 \%$ & $0.5 \%$ & $4.0 \%$ \\
\hline Response Frequency, hz. & 8.39 & 0.194 & 7.11 \\
\hline $\begin{array}{c}\text { Response Spectral } \\
\text { Acceleration, } \mathrm{g}\end{array}$ & 0.78 & 0.099 & 0.54 \\
\hline
\end{tabular}

* Based on Table 3.2 of the TSEP Guidelines (reference 1) for response level 3.

\section{Sloshing Evaluation}

A sloshing evaluation was performed as required by the TSEP Guidelines (reference 1). Using the TSEP Guidelines, the slosh height was calculated to be 37.3 inches. The total demand height is 68.6 inches, obtained by factoring the required slosh height by a safety factor of 1.6, and a seismic load factor of 1.15. The slosh height capacity is 51.25 inches, accounting for the freeboards available in the cylindrical portion and (one-quarter of the) dome space of the tank. Since the slosh height demand exceeds the capacity, either the liquid level must be lowered or the tank must be designed to withstand the adverse effects of inadequate freeboard. The latter option is more cost-effective and, therefore, has been adopted in the analysis.

In a tank with inadequate freeboard the sidewall pressure will increase due to the constraint of the sloshing liquid by the roof. Mathematically, this situation can be idealized by treating a portion the liquid as being "attached" to the tank wall, i.e., accelerating with the acceleration of the tank wall. However, the ratio of the mass of this portion of liquid to the total mass is unknown. A conservative upper bound of this ratio, however, is the difference between the total mass of the liquid and the mass of the portion already responding in the impulsive mode. In the case of the MWTF, the fraction of the mass responding in the impulsive mode is 0.53 , and therefore, the conservative estimate of the liquid mass fraction causing the sidewall pressure increase is 1 minus 0.53 , or 0.47 . For tanks having adequate freeboard, this fraction of mass responds with the convective acceleration $(0.099 \mathrm{~g}$ 's in the case of the MWTF; see Table 2). However, if the freeboard is not adequate, the same fraction of mass will respond with a higher acceleration, conceivably as high as the impulsive spectral acceleration $10.78 \mathrm{~g}^{\prime} \mathrm{s}$ in the case of the MWTF), with a heightwise variation of the convective pressures. Based on this explanation, a conservative estimate of the increased convective pressures on the sidewalls can be obtained by factoring the customary convective pressures shown dashed in Figure 5 by the ratio of the impulsive to convective spectral accelerations, or $0.78 / 0.099=7.88$. 'The convective pressures thus factored to account for the inadequate freeboard are also shown in Figure 5. It is also noted that, since as explained above, this increased pressure is caused by the spectral impulsive acceleration, the impulsive and increased convective pressure effects are combined in an additive manner, 
which is conservative in comparison to the square-root-of-the-sum-of-the-squares (SRSS) method of combination ordinarily used.

Convective pressures will also act upon those portions of the tank above the liquid surface. Therefore, the increased sidewall convective pressure distribution described above is extended above the liquid surface in accordance with Equation (4.3) of reference 1.

\section{Operating Plus Seismic Loads (Service Level D) Analysis}

The calculated hydrodynamic pressures, including the pressures resulting from inadequate freeboard, were applied to the previously described finite element tank model. A load combination was performed to combine the normal operating loads with the seismic hydrodynamic loads. The inertia effects of the tank itself must also be added to the hydrodynamic effects. However, as stated in Section 4.3.6 of the TSEP Guidelines, for top-supported tanks and tanks for which the roof mass is not substantial compared with that of the contained liquid (such as the MWTF tanks), the effects of tank's self inertia are negligible compared with the hydrodynamic effects. Therefore, the tank inertia effects are ignored hereafter. Although the impulsive and convective hydrodynamic pressures are exerted only on one-half of the tank depending on the direction of horizontal earthquake component, they are applied in a non-axisymmetric manner in the circumferential direction, i.e., with a cosine $\theta$ variation where $0^{\circ} \leq \theta \leq 360^{\circ}$. This implies negative impulsive and convective pressure applications for $90^{\circ} \leq \theta \leq 270^{\circ}$. However, negative pressures are not realistic; therefore, the results are only evaluated for $-90^{\circ} \leq \theta \leq 90^{\circ}$.

A supplementary analysis has been performed to verify the validity of the assumption implicit in the above paragraph. The analysis showed that the use of a two-dimensional axisymmetric model, and, therefore, the application of negative horizontal pressures for $90^{\circ} \leq \theta \leq 270^{\circ}$, does not significantly affect the results at $\theta=0^{\circ}$ which is the location of maximum responses. A three-dimensional finite element model of the primary storage tank structure has been constructed for the purposes of this supplementary analysis. Figure 6 shows the model and the distribution of the hoop membrane stresses in that model under the impulsive pressure loading. Since the structure and the loading are symmetric, only one-half of the tank $\left(0^{\circ} \leq \theta \leq 180^{\circ}\right)$ is modeled, and the impulsive pressures are applied with a cosine $\theta$ distribution for $0^{\circ} \leq \theta \leq 90^{\circ}$ in the circumferential direction and the distribution shown in Figure 5 in the meridional direction. The threedimensional model has a smaller number of elements in the meridional direction than the two-dimensional axisymmetric model (20 versus 96 elements). Nonetheless, the comparison of the results of the two and three-dimensional models shows that similar results are obtained in both cases, and thus the assumption that the two-dimensional axisymmetric model is adequate for the evaluation of the stresses at the critical circumferential location of $\theta=0^{\circ}$ is verified. The results at $\theta=0^{\circ}$ are in good agreement since, for example, the maximum hoop membrane stresses calculated by the use of three and two-dimensional models are 6970 psi and 7096 psi, respectively. 
Since per the TSEP Guidelines earthquake loading is considered to be a service level $D$ loading, the stresses obtained using the axisymmetric model are evaluated against the ASME B\&PV Code, Section III, Division 1, subsection NC, level D allowables. The service limits shown in the ASME code are as follows:

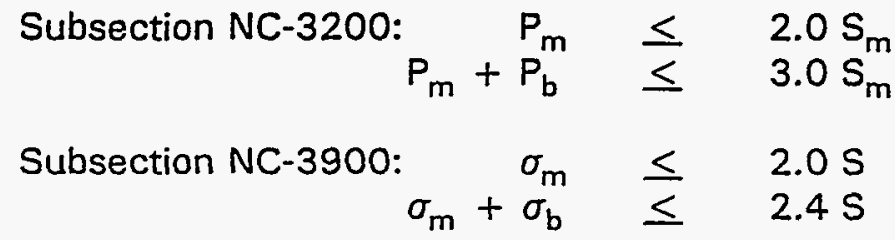

where the terms are as defined previously.

Table 3 summarizes the results of this evaluation. Figure 7 shows the displaced shape under the applied service level $D$ loads. According to the results shown in Table 3, all the evaluated stress components are less than their corresponding allowables, and therefore, the tank design is acceptable under service level $D$ loads.

Table 3 -- ASME Code Stress Evaluations Under Normal Operating plus Seismic Loads

\begin{tabular}{|c|c|c|}
\hline . & Stress (ksi) $\quad \therefore$ & $\begin{array}{l}\text { Allowable Stress } \\
\text { at Temperature (ksi) }\end{array}$ \\
\hline $\begin{array}{l}\text { Membrane Stress Intensity } \\
\text { per NC-3200 }\end{array}$ & 26.64 & 45.60 \\
\hline $\begin{array}{l}\text { (Membrane + Bending) Stress } \\
\text { Intensity per NC-3200 }\end{array}$ & 36.56 & 68.40 \\
\hline $\begin{array}{l}\text { Membrane Stress } \\
\text { per NC-3900 }\end{array}$ & 26.61 & 35.00 \\
\hline $\begin{array}{l}\text { (Membrane + Bending) Stress } \\
\text { per NC-3900 }\end{array}$ & 27.32 & 42.00 \\
\hline
\end{tabular}

\section{Seismic Capacity Evaluations per the TSEP Guidelines}

Chapter 5 of the TSEP Guidelines provides an approach to performing seismic capacity evaluations by hand calculations of either anchored or unanchored flat-bottom metal liquid storage tanks. The following seismic capacities of the primary storage tanks were evaluated in accordance with the TSEP Guidelines as an alternate to the finite element analysis.

Base Shear Capacity: The base shear capacity provided by friction is calculated to be 6,144 kips, and exceeds the sliding base shear load of 5,556 kips. The shear stress in the tank metal cross section area at the bottom of the tank is calculated to be 2.07 $\mathrm{ksi}$, which is much less than the tank metal allowable shear stress of $13.66 \mathrm{ksi}$.

Hoop Tension: The calculations show that the pressure capacities $\left(P_{c}\right)$ exceed the total inelastic-factored demand pressure $\left(P_{t i}\right)$ by a substantial margin. The summary results are shown in Table 4. 
Table 4 - Pressure Capacities $\left(P_{c}\right)$ Versus Inelastic Demand Pressure $\left(P_{\mathrm{ti}}\right)$

\begin{tabular}{|c|c|c|}
\hline Location on tank & $\mathbf{P}_{\mathrm{tj}}$ (psi) & $\mathbf{P}_{\mathrm{c}}$ (psi) \\
\hline $\begin{array}{c}\text { Bottom knuckle-to-tank wall tangent } \\
\text { intersection point }\end{array}$ & 43.25 & 73.89 \\
\hline $\begin{array}{c}\text { Point where the wall shell course } \\
\text { thickness changes from 1 in. to } 7 / 8 \text { in. }\end{array}$ & 37.04 & 64.17 \\
\hline
\end{tabular}

\section{Evaluation of Compressive Stresses}

Compressive stresses at various locations of the primary storage tank structure were calculated by the finite element analyses and were compared with allowable stresses. The summary results of those comparisons are shown in Table 5. As shown in Table 5, all the demand stresses are less than the corresponding allowables; therefore, the tank design is acceptable in terms of the compressive stresses.

\section{Evaluation of Bottom Plate Areas not Supported by Concrete}

Local bending stresses were evaluated in the tank bottom plate areas where no concrete support is provided; i.e., at the central air-distribution chamber, nondestructive examination slots, and air-distribution slots. The first two locations are identified as critical because of their large plate spans. Pressure normal to the plate in these regions causes local bending stresses that must not exceed the ASME code allowables for service levels $A, B$, and D. Membrane stresses alone are not checked since their values are unchanged from those already evaluated as described above. The previously calculated membrane plus bending thermal stresses are added to the bending stresses at the extreme fibers to obtain the membrane plus bending stress and stress intensity components.

Conservative assumptions are made, such as simply supported edges and a full tank.

Portion of Bottom Plate at the Central Air Distribution Chamber: For service level $A$, the pressure is computed by adding fluid weight, steel plate weight, and vapor pressure. For level $B$, membrane plus bending thermal stresses are obtained from the axisymmetric analysis described earlier and added to stresses obtained from level $A$. For level $D$, the pressure from level $A$ is increased by the vertical hydrodynamic component shown in Figure 5 . The stress results are summarized in Table 6.

Bottom Plate at the Nondestructive Examination Slots: For service level A, the pressure is the same as that used for the central air distribution chamber. For level $B$, membrane plus bending thermal stresses are obtained from the axisymmetric tank analysis. For level $D$, the pressure from level $A$ is increased by three hydrodynamic maximum components; i.e., the impulsive, vertical and convective pressures shown in Figure 5. The stress results are summarized in Table 6. 
Table 5 -- Summary Results of the Compressive Stress Evaluations

\begin{tabular}{|c|c|c|c|c|c|}
\hline Location & $\begin{array}{l}\text { Load } \\
\text { Combination }\end{array}$ & $\begin{array}{l}\text { Evaluation } \\
\text { Criteria }\end{array}$ & $\begin{array}{l}\text { State of } \\
\text { Stress }\end{array}$ & $\begin{array}{l}\text { Demand: } \\
\text { Stress (ksi) }\end{array}$ & $\begin{array}{l}\text { Allowable } \\
\text { Stress (ksi) }\end{array}$ \\
\hline $\begin{array}{c}\text { Top } \\
\text { Knuckle }\end{array}$ & $\begin{array}{c}\text { Normal } \\
\text { Operating }+ \\
\text { Seismic } \\
\text { Pressure } \\
\end{array}$ & $\begin{array}{c}\text { ASME } \\
\text { NC-3922.3, } \\
\text { Paragraph d }\end{array}$ & $\begin{array}{c}\text { Hoop } \\
\text { Compression, } \\
\text { Meridional } \\
\text { Tension } \\
\end{array}$ & 5.39 & 8.82 \\
\hline \multirow[t]{4}{*}{ Cylinder } & \multirow[t]{4}{*}{$\begin{array}{l}\text { Normal } \\
\text { Operating }+ \\
\text { Secondary } \\
\text { Loads }^{(1)}\end{array}$} & $\begin{array}{c}\text { TSEP } \\
\text { "Elephant Foot } \\
\text { Buckling" }\end{array}$ & $\begin{array}{l}\text { Meridional } \\
\text { Compression }\end{array}$ & $\begin{array}{c}0.63^{(2)} \\
0.69 \\
0.78\end{array}$ & $\begin{array}{l}8.12 \\
7.57 \\
7.01\end{array}$ \\
\hline & & $\begin{array}{c}\text { TSEP } \\
\text { "Diamond } \\
\text { Buckling" }\end{array}$ & $\begin{array}{l}\text { Meridional } \\
\text { Compression }\end{array}$ & $\begin{array}{c}0.63^{(2)} \\
0.69 \\
0.78 \\
\end{array}$ & $\begin{array}{l}5.59 \\
4.85 \\
4.12 \\
\end{array}$ \\
\hline & & $\begin{array}{c}\text { ASME } \\
\text { NC-3922.3, } \\
\text { Paragraph d }\end{array}$ & $\begin{array}{l}\text { Meridional } \\
\text { Compression, } \\
\text { Hoop Tension } \\
\end{array}$ & $\begin{array}{c}0.63^{(2)} \\
0.69 \\
0.78 \\
\end{array}$ & $\begin{array}{l}2.14 \\
3.30 \\
2.80 \\
\end{array}$ \\
\hline & & $\begin{array}{c}\text { ECCS } \\
\text { (reference 3) }\end{array}$ & $\begin{array}{c}\text { Meridional } \\
\text { Compression, } \\
\text { Hoop Tension } \\
\end{array}$ & $\begin{array}{c}0.63^{(2)} \\
0.69 \\
0.78 \\
\end{array}$ & $\begin{array}{l}5.03 \\
4.64 \\
4.29 \\
\end{array}$ \\
\hline \multirow[t]{2}{*}{$\begin{array}{l}\text { Bottom } \\
\text { Knuckle }\end{array}$} & \multirow[t]{2}{*}{$\begin{array}{l}\text { Normal } \\
\text { Operating }+ \\
\text { Secondary } \\
\text { Loads }^{(1)}\end{array}$} & $\begin{array}{c}\text { ASME } \\
\text { NC-3922.3, } \\
\text { Paragraph c }\end{array}$ & $\begin{array}{c}\text { Meridional } \\
\text { Compression, } \\
\text { Hoop } \\
\text { Compression }\end{array}$ & 0.77 & 0.92 \\
\hline & & $\begin{array}{c}\text { ASME } \\
\text { NC-3922.3, } \\
\text { Paragraph } \mathrm{d}^{(3)}\end{array}$ & $\begin{array}{l}\text { Meridional } \\
\text { Compression, } \\
\text { Hoop Tension }\end{array}$ & 0.58 & 0.59 \\
\hline
\end{tabular}

Although not required by the ASME Code, secondary loads, i.e., thermal expansion and creep induced top displacement loads, are conservatively included in the compressive stress evaluations of the portion of the tank in contact with the liquid. Hydrodynamic pressure loading does not increase the compressive stress values used in the evaluation, and therefore, are not included in the load combinations.

(2)

The three values shown are for the three shell course thicknesses of $1,7 / 8$ inches and $3 / 4$ inches, respectively.

(3)

Allowable stress criteria could not have been satisfied had the bottom knuckle thickness not been increased to $1-1 / 8$ inches. 
Table 6 - Stresses in the Bottom Plate

\begin{tabular}{||c|l|c|c|c|}
\hline \multirow{2}{*}{ Service Level } & $\begin{array}{c}\text { Stress Component } \\
\text { (Membrane + Bending) }\end{array}$ & $\begin{array}{c}\text { Stress } \\
\text { (ksi) }\end{array}$ & $\begin{array}{c}\text { Stress }^{2} \\
\text { (ksi) }\end{array}$ & $\begin{array}{c}\text { Allowable } \\
\text { Stress (ksi) }\end{array}$ \\
\hline \multirow{2}{*}{ B } & Stress Intensity & 17.57 & 4.73 & 34.20 \\
\cline { 2 - 5 } & Stress & 17.57 & 4.73 & 26.25 \\
\hline \multirow{2}{*}{ D } & Stress Intensity & 18.53 & 20.43 & 68.40 \\
\cline { 2 - 5 } & Stress & 18.53 & 20.43 & 28.88 \\
\hline & Stress Intensity & 24.30 & 10.02 & 68.40 \\
\cline { 2 - 5 } & Stress & 24.30 & 9.96 & 42.00 \\
\hline
\end{tabular}

$1 \quad$ Stress at the central air distribution chamber

2 Stress at the nondestructive examination slots

\section{Negative Pressure Evaluation}

Evaluations were performed to determine the effect of a negative pressure of $0.22 \mathrm{psi}$, equivalent to that of -6 inches of water, inside the primary tank on bottom plate uplift and wall buckling. The evaluations are in accordance with ASME NC-3932.6, Special Considerations Applicable to Bottoms Resting Directly on Foundations, and ASME NC3133.3, Components Under External Pressure, Cylindrical Shells and Tubular Products, respectively.

Bottom Plate Uplift Evaluation: Per ASME NC-3932.6, a weight equilibrium method based on net thicknesses of the material, exclusive of corrosion allowance, is used to demonstrate that the bottom plate will not experience uplift due to a negative pressure of -6 inches. The tank is considered as completely empty in the evaluation. This is conservative since the weight of any fluid in the base resists uplift. The weight of the bottom plate, which is 0.8 inch thick ( 1 inch less the 0.2 inch erosion and corrosion allowance), is equivalent to that of 6.28 inches of water. Because this value exceeds the uplift pressure of 6 inches of water, it is concluded that the bottom plate will not experience uplift.

Wall Buckling Evaluation: ASME NC-3133.3 rules are implemented for calculating the allowable external pressure, which is the same as an allowable internal negative pressure, on the primary tank wall. In performing this analysis, conservative assumptions are made such as a cylinder length of about 500 inches and a uniform nominal wall thickness of 0.75 inches, which is the minimum nominal wall thickness. A 0.05 inch allowance for corrosion is considered. It is found that the wall buckling capacity under internal negative pressure is equivalent to that of 20.88 inches of water. Therefore, the wall will not buckle under an internal negative pressure of 6 inches of water. 
Minimum Wall Thickness Calculations

Calculations were performed to verify the adequacy of the wall thicknesses of the dome, cylindrical tank, and the lower knuckle using the criteria specified in NC-3900. The minimum wall thicknesses were also checked for the hydrotest condition since the entire dome will be unanchored during the hydrotest. Because the hydrotest pressure is $25 \%$ higher than the design pressure, the tensile stress allowables for this evaluation are assumed to be $25 \%$ higher than the service level $A$ allowables.

The actual thicknesses for the anchored (backed by concrete) and unanchored portions of the dome are $1 / 2$ inch and $3 / 4$ inch, respectively. Although, by analysis, the necessary thickness in the anchored portion is found to be only $3 / 8$ inch, the thickness is increased to $1 / 2$ inch to account for the large number of penetrations and to allow for potential corrosion due to condensation. In the anchored portion, both the meridional and hoop stresses are tensile. The maximum stress is calculated to be $7,045 \mathrm{psi}$, which is significantly lower than the allowable tensile stress of 21,687 psi. In the unanchored portion of the dome, the meridional stress is compressive. The maximum compressive stress of 10,248 psi occurs at the dome and cylindrical shell junction. The allowable compressive stress is calculated to be 14,500 psi.

As shown in Figure 1 the cylindrical shell thickness varies from $3 / 4$ inch to 1 inch. For the thickness calculation, the worst case occurs when the tank is filled with liquid waste to the maximum allowable height and the pressure in the vapor space is equal to the maximum positive design pressure (2.89 psi). The critical location for the cylindrical shell is its junction with the lower knuckle. The meridional and hoop stresses are tensile at this location. The minimum required thickness, including a 50-year-life corrosion allowance of 0.05 inch, is calculated to be 0.724 inch, and this is less than the 1 inch thickness available at that location.

The lower knuckle has a radius of 24 inches and is $1-1 / 8$ inches thick. For the normal operating condition and design pressure in the vapor space, the required thickness at the cylinder-knuckle junction is 0.116 inch, which includes a corrosion allowance of 0.05 inch. However, the hydrotest condition is the critical case since the meridional stress becomes compressive for this case. The minimum thickness required in this case is 1 inch, resulting in a compressive stress of 11,318 psi. This is less than the allowable compressive stress of 14,580 psi calculated for a 1 inch thick wall. Although the minimum thickness required to satisfy ASME Code Subsection NC-3900 is 1 inch, the lower knuckle thickness has been increased to $1-1 / 8$ inches to satisfy the compressive stress requirements as shown in Table 5.

Therefore, based on the preceding discussion, the selected dome, tank, and lower knuckle thicknesses are adequate and meet the minimum thickness requirements of NC-3932.

\section{Parametric Evaluations}

The bottom knuckle radius of 24 inches appearing in Figure 1 was determined as a result of a parametric evaluation. The objective of this study was the determination of the optimum bottom knuckle radius since increasing the radius has compensating effects on the stresses resulting from different loadings, i.e., increasing the knuckle radius helps 
reduce the thermal stresses whereas it causes an increase in the stresses due to hydrostatic pressure loading.

Another parametric study was performed to determine the optimum location of the connection point between the primary storage tank steel and the secondary tank concrete; i.e., the location of node 97 of the axisymmetric finite element model. As intuitively apparent, the closer this point is to the tank vertical centerline, the more flexible the primary storage tank springline will be and, therefore, the less the thermal stresses will be. These intuitive observations were borne out by the parametric evaluations. However, the location of the connection point was left unaltered as this alteration could have impacted other design activities and the benefits of the alteration were deemed to be insignificant.

Other evaluations performed during the earlier phases of the design included those using:

- Different materials such as SA-240 Type 304L stainless steel and SA-537 Class 1 carbon steel.

- Different seismic, thermal and top displacement boundary condition loading levels.

\section{REFERENCES.}

1. Tank Seismic Experts Panel Report, Seismic Design and Evaluation Guidelines for the Department of Energy, High-Level Waste Storage Tanks and Appurtenances, Report No. BNL 52361, Brookhaven National Laboratory, January 1993.

2. Swanson Analysis Systems, Inc., ANSYS, Rev. 5.OA.

3. Buckling of Steel Shells - European Recommendations, European Convention for Constructional Steelwork, Fourth Edition, 1988. 
Figure 1 -- Structural Tank Cross Section

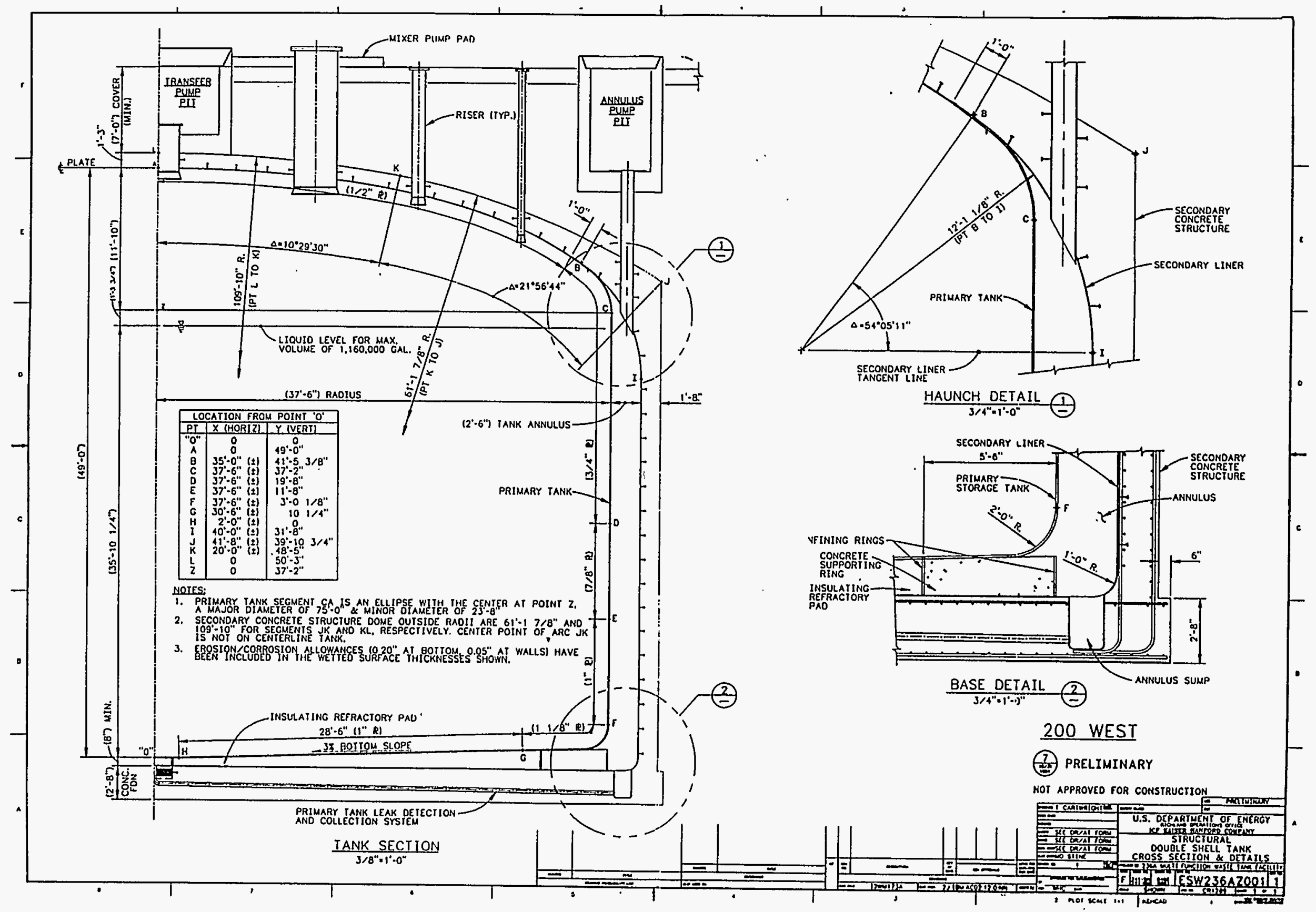


Figure 2 - The Finite Element Model

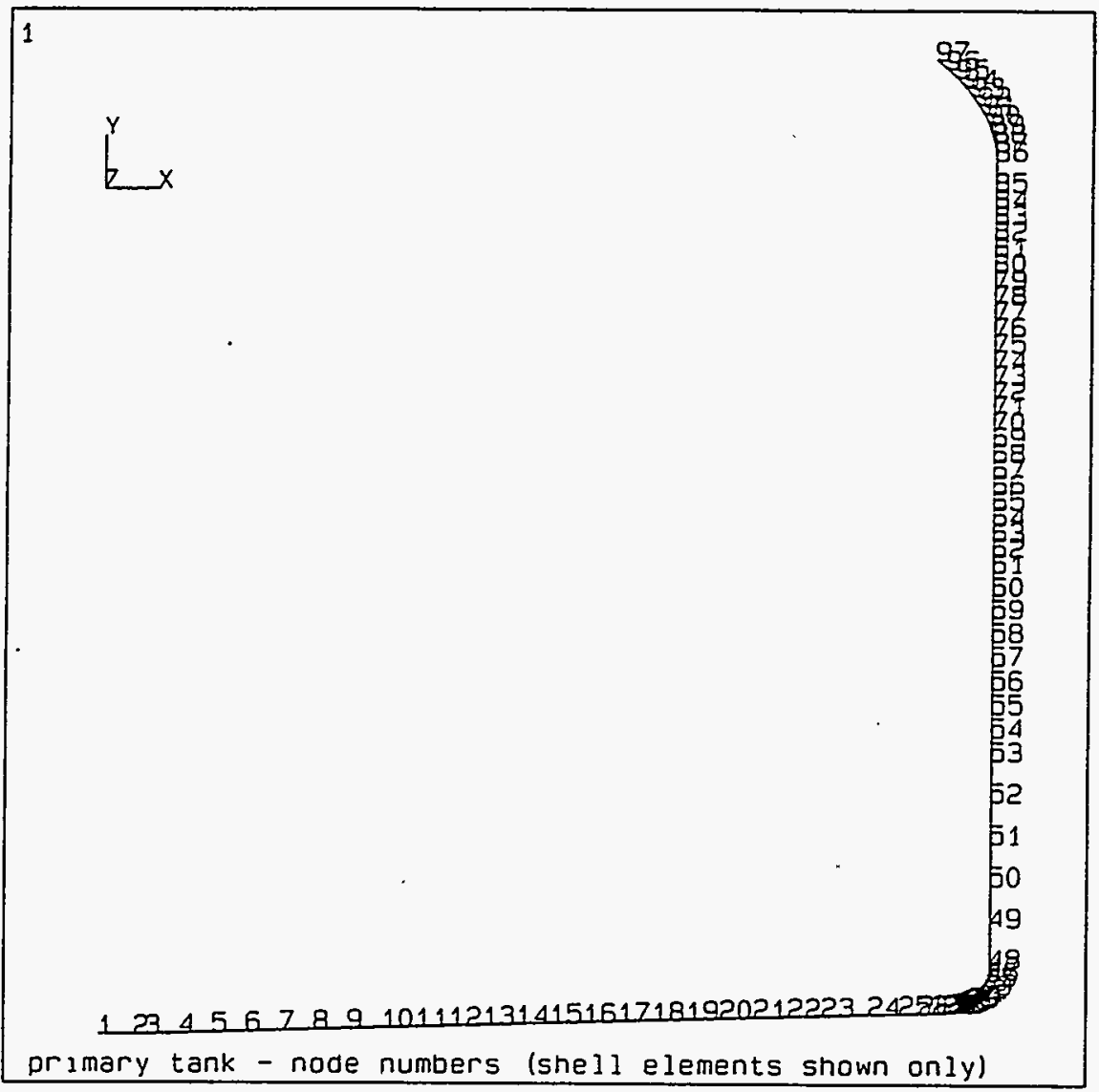

ANSYS 5 . 0 A

11: $21: 54994$

TYEMENTS

PYPE NUM

$\begin{aligned} Z V & =1 \\ D I S T & =273.343\end{aligned}$

YF $=-225.756$

primary tank - node numbers (shell elements shown only)

Figure 3 - Displaced Shape under Service Level A Loads

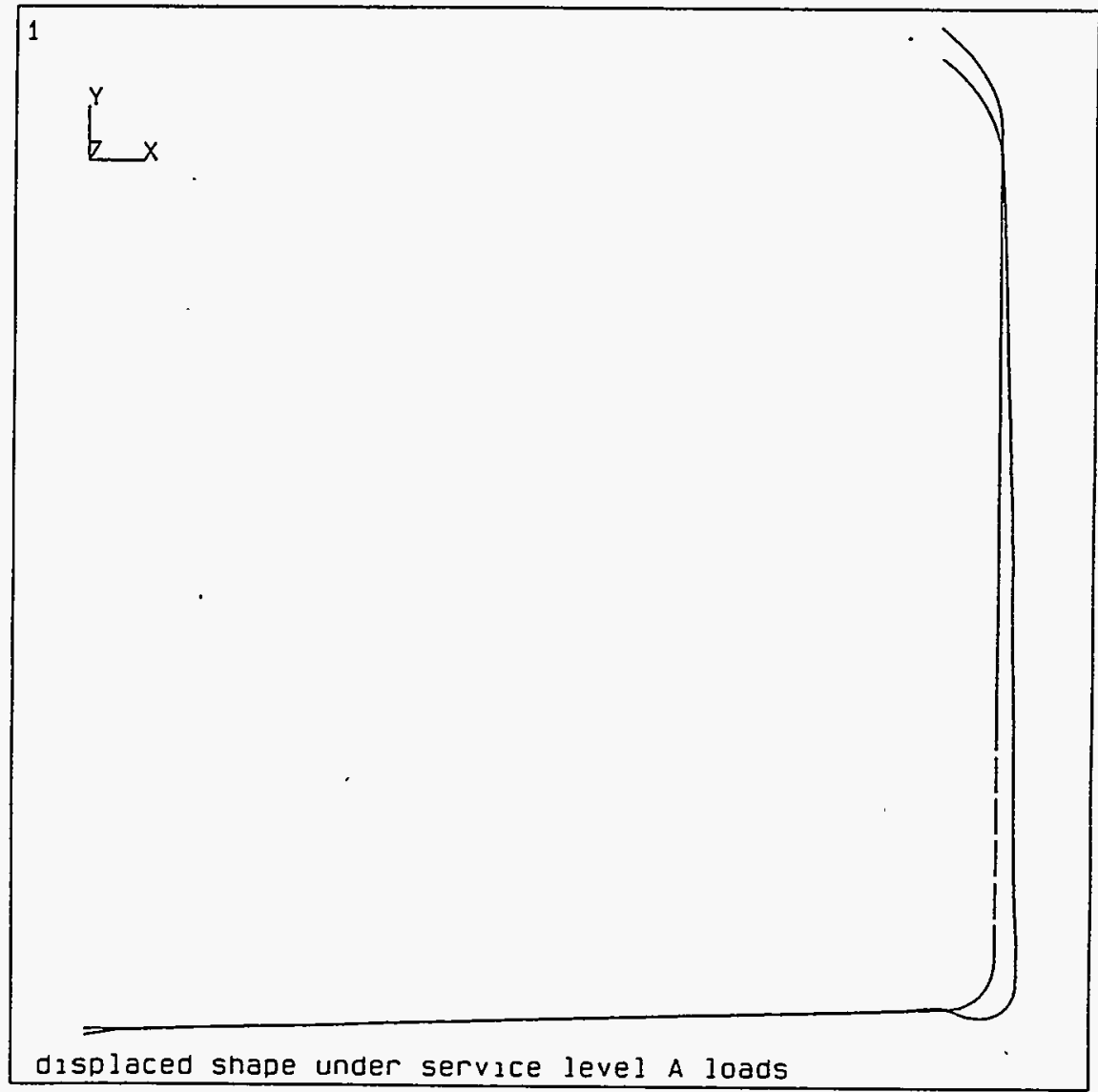


Figure 4 - Displaced Shape under Service Leval B Loads

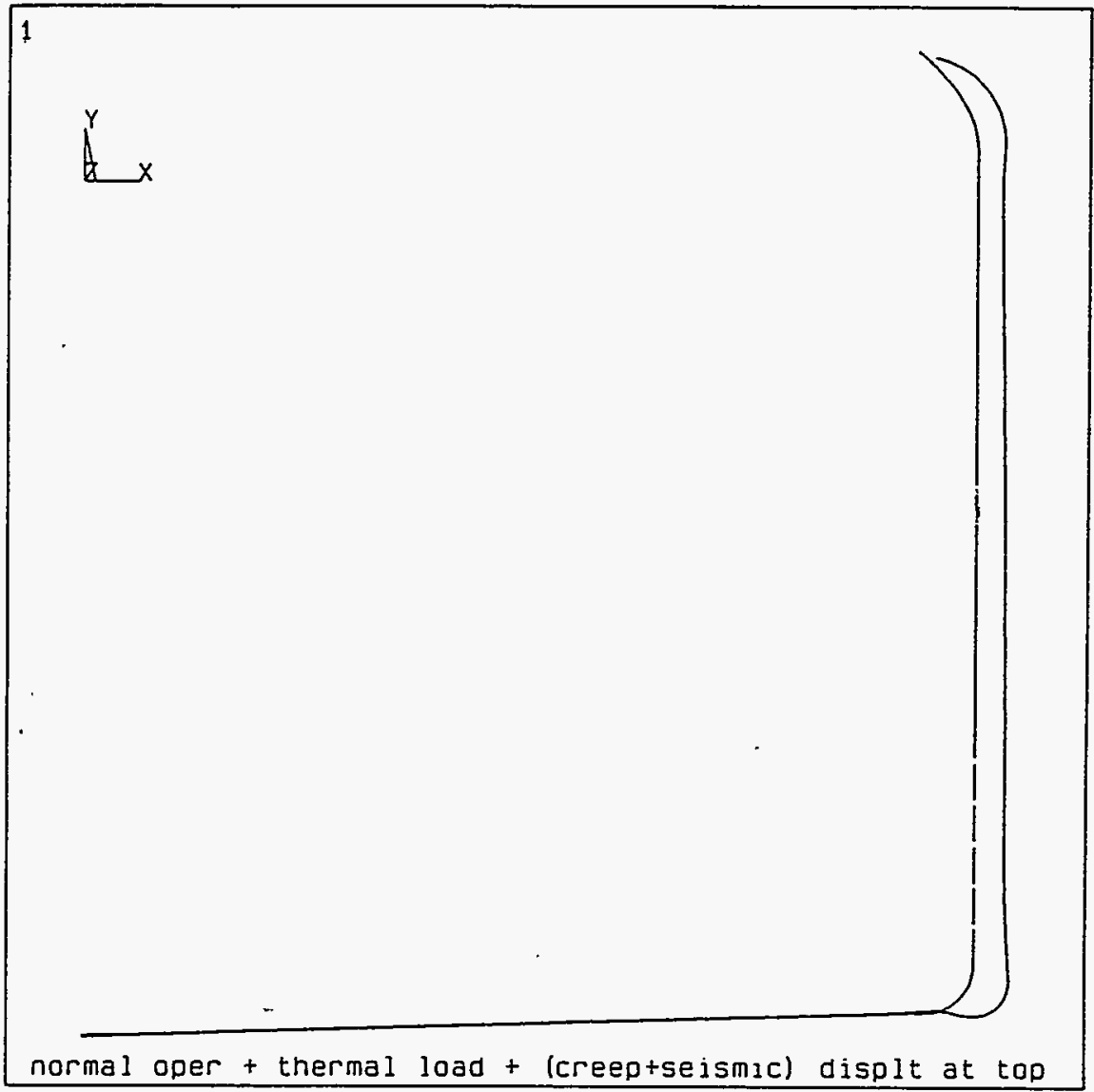

ANSYS 5 . A

16: 34 ? 1994

PLOT NÓ

QLST NO

SUE $=$

OMX $=0.98531$

$* D S C A=20$

DIST $=272.391$

XF $=233$ 列

CENTROOIO HIDOEN

normal oper + thermal load + (creeptseismic) displt at top

Figure $\mathbf{5}$ - Hydrostatic and Hydrodynamic Pressures

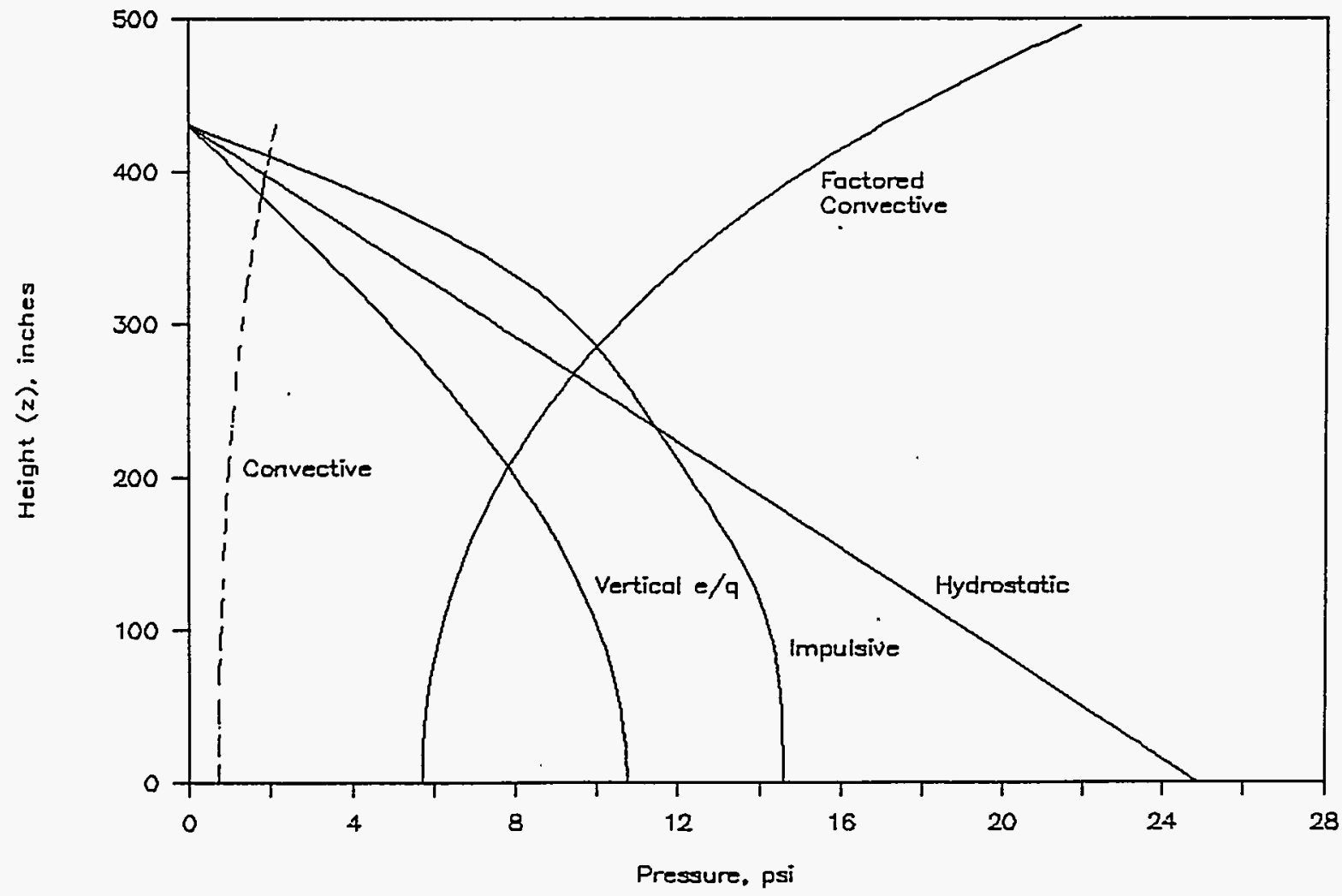




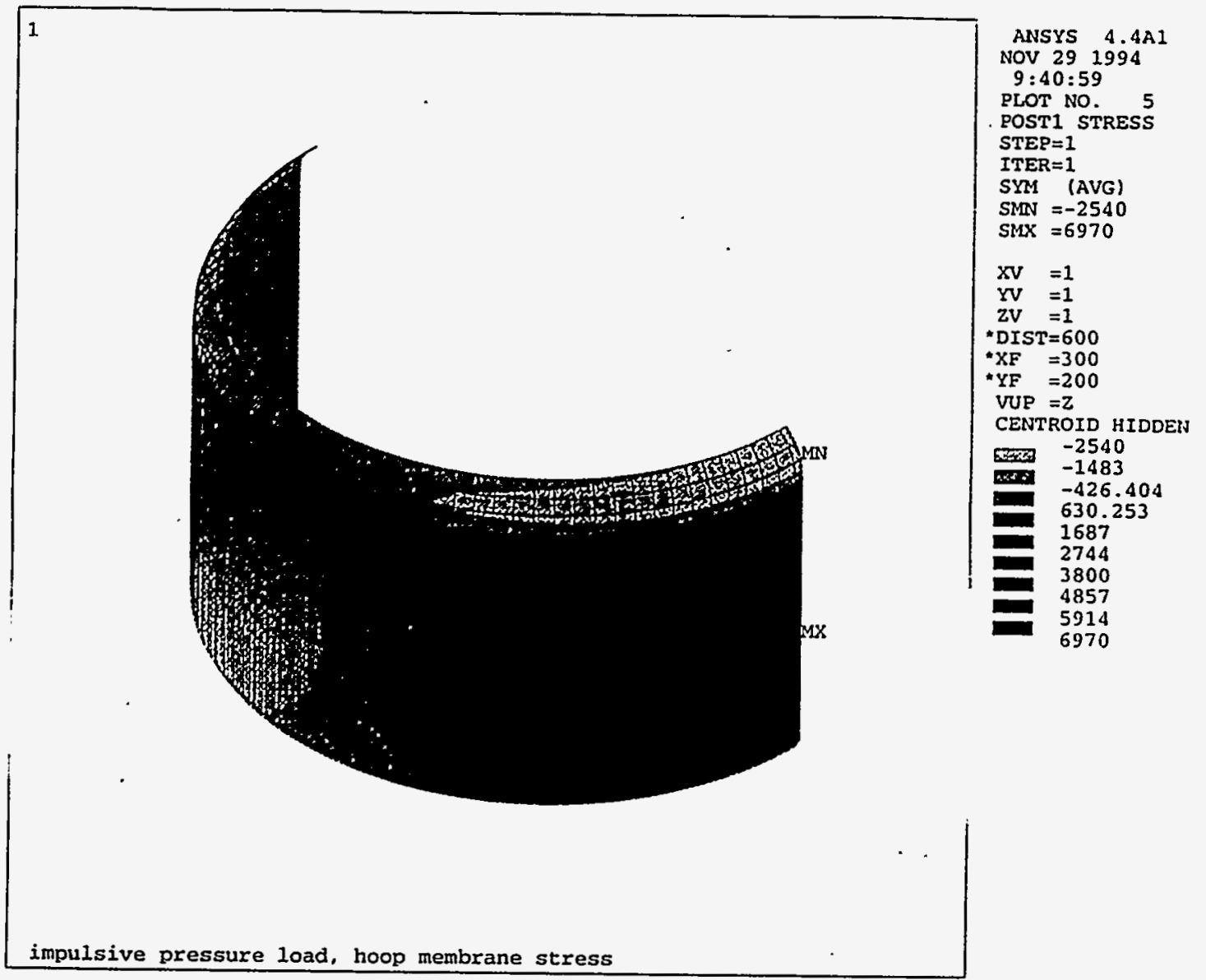

Figure 7 - Displaced Shape under Service Level D Loads

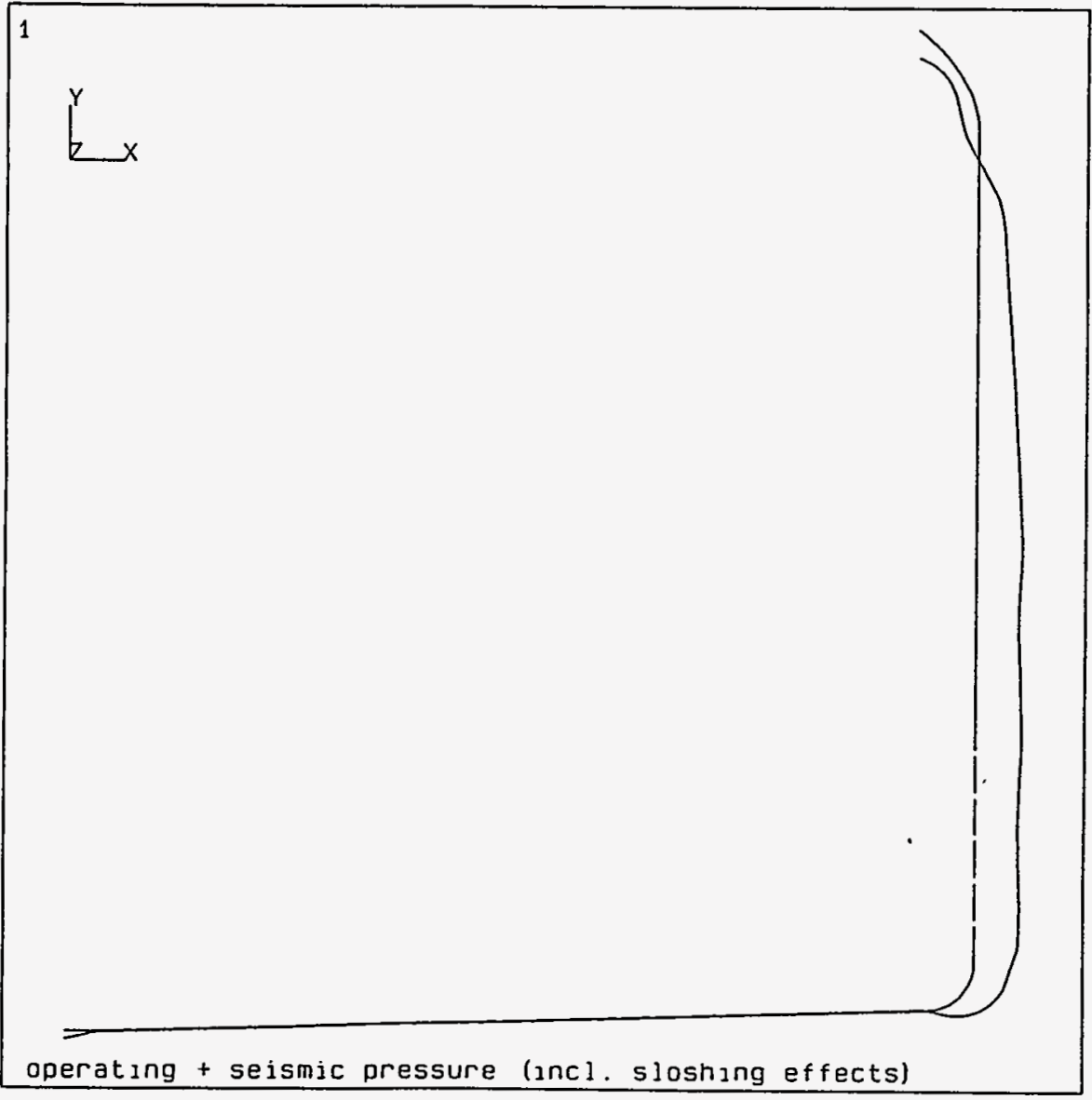

ANSYS 5 .O A

NOV 28 ig9 36

PLOT NO

DISPLACEMMENT

STEP $=9999$

RSYS $=0$

$D M X=0.538559$

$\mathrm{OSCA}=50.755$

DV IST $=267.525$

$\begin{aligned} \mathrm{XIST} & =267 \cdot 525 \\ & =236: 385\end{aligned}$

VF $=-190$. 